DOI: https://doi.org/10.18371/fp.4(44).2021.175181

УДК 338.1

\title{
СУЧАСНИЙ СТАН МАЛОГО ТА СЕРЕДНЬОГО БІЗНЕСУ В УМОВАХ КОРОНОВІРУСНИХ ОБМЕЖЕНЬ
}

\author{
ЯРМОЛЕНКО Віталіна Вікторівна \\ асистент кафедри економіки та фінансів \\ Херсонський державний аграрно-економічний університет \\ ORCID ID: http://orcid.org/0000-0001-7567-0082
}

\begin{abstract}
Анноватція. $У$ статті розглянуто стан малого та середнього бізнесу України та зарубіжних краї в умовах пандемії COVID19. Визначено, щзо на МСБ негативно впливають карантинні обмеження. Виявлено, щзо більшість країн послабили податкові платежі, вводили «кредитні канікули» для підприємств, які не взмозі платити, виплачувалися допомога підприємствам для оплати прачі прачівникам тощуо. Запропоновано способи подолання нинішньої економічної кризи бізнесу та економіки.

Ключові слова: економіка, криза, малий бізнес, середній бізнес, податки, відсоткові ставки, пандемія, карантин, COVID-19.
\end{abstract}

Постановка проблеми. За останні кілька років в Україні погіршився стан економіки, на що суттєво вплинула всесвітня пандемія COVID-19. За таких умов сфера малого та середнього підприємництва $є$ одними з найбільш постраждалих категорій суб'єктів господарювання, 3 яких значна їх частка функціонує у секторах економіки, де бізнес не отримав належної державної підтримки, в результаті чого велика частина цих підприємств збанкрутувала. Спираючись на досвід розвинених країн, реалізація збалансованої фінансової політики підтримки державою
Аннотация. $B$ cтатье рассмотрено состояние малого и среднего бизнеса Украины и зарубежных краев в условиях пандемии COVID-19. Определено, что на МПБ негативно влияют карантинные ограничения. Выявлено, что большинство стран ослабили налоговые платежи, вводили «кредитные каникуль»» для предприятий, которые не в состоянии платить, выплачивались пособия предприятиям для оплаты труда работникам и т.д. Предложены способы преодоления нынешнего экономического кризиса бизнеса и экономики.

Ключевые слова: экономика, кризис, мальий бизнес, средний бизнес, налоги, прочентные ставки, пандемия, карантин, COVID19.

суб'єктів малого бізнесу є невід'ємною частиною сучасної фінансової політики у державній сфері. В умовах кризи економічного розвитку саме державна допомога малому бізнесу може призвести до покращення економічної ситуації в регіонах і по всій країні. Сьогодні саме у малому та середньому бізнесі держава сподівається на швидкі позитивні структурні зміни в економіці, подолання економічної кризи та створення умов для економічного зростання.

Аналіз останніх досліджень і публікацій. Питаннями впливу пандемії 
COVID-19 на економічні процеси, особливо на малих і середніх підприємствах, займалися такі зарубіжні науковці, як Річард Болдуін та Беатріс Ведер [1], Джозеф Аманква-Амоа, Захір Хан, Джеффрі Вуд [2]. Наразі не існує комплексного погляду на проблему в українській економіці, проте ведуться активні дослідження такими науковцями, як А.Ворфоломеєв [3], Д. Дєнков, А. Каракуц, Ю. Щедрін [4], С. Свєшніков, В. Бочарніков, О. Полякова [5] та іншими. Проте, зважаючи на динамічний розвиток ситуації та хвильовий характер пандемії, дослідження впливу карантинних заходів на економіку, особливо на малий та середній бізнес, $є$ недостатньо повними.

Метою статті є виявлення чинників впливу пандемії COVID-19 на функціонування малого та середнього бізнесу, розробка можливих способів подолання іï наслідків або їх мінімізація.

Виклад основного матеріалу дослідження. Малий та середній бізнес (МСБ) $є$ фундаментом для всієї економіки держави. Саме сектор МСБ $є$ основним у забезпеченні зайнятості, на нього в Україні припадає близько 79\% від всієї кількості робочих місць, а також він виступає основою соціальної та трудової сфери. Це підтверджує практичний вітчизняний та зарубіжний досвід. Карантин, спричинений пандемією COVID-19, в тому числі й в Україні, паралізував функціонування або взагалі привів до закриття середніх, малих та мікропідприємств. На сьогодні в Україні функціонує майже 1,8 мільйона малих і середніх підприємств (16,5 тисяч середніх, 339 тисяч малих, 1,48 млн індивідуальних підприємців (ФОП) та лише 446 великих підприємств). Як юридичні особи функціонує лише 19,8\% МСП, решта підприємств ведуть свою господарську діяльність як індивідуальні підприємці (ФОП) [6].

Введення карантину спричинило негативний вплив на функціонування МСБ. Запроваджені обмеження призвели до:

- деякі сектори не мали змоги повноцінно вести свою господарську діяльність через заборону або обмеження у веденні діяльності;

- зменшення доходів, у зв'язку зі зростанням безробіття, провело до зниження платоспроможності населення, а це, в свою чергу, до зменшило попиту на продукцію підприємств;

- значна частина суб'єктів МСБ не витримала жорстких обмежень та вимушені були припинити свою діяльність;

- деякі малі та середні підприємств не мають у своєму розпорядженні необхідних фінансових ресурсів для швидкого та ефективного подолання негативних наслідків пандемії COVID19 ;

- зросла тенденція тіньового сектору зайнятості та збільшилось приховане безробіття;

Більше негативного впливу від пандемії зазнали ті малі та середня підприємства, які функціонують у сфері харчування, сфері надання послуг та сфері торгівлі. Менший вплив відчули підприємства, які працюють у сфері нерухомості, консалтингових, юридичних послуг тощо. За даними Спілки українських підприємців України [7] у березні 2020 року втратили свій бізнес близько $6 \%$ власників малих підприємств, що стало великою проблемою для економіки держави. Приблизно 1/3 мікро- бізнесу (рідше малих підприємств) отримали доходів за бере- 
зень - квітень 2020 року менше на 90$100 \%$. В результаті чого їм довелося скорочувати штати і тому було звільнено 50\% працівників. Власники МСБ недоотримали доходів на 25-50\%, порівнюючи 3 аналогічним докарантинним періодом і скоротили штат співробітників на 10- 25\%. Порівнюючи зі втратами великих підприємств, які становили $10-25 \%$ від доходів та скороченням штату до $20 \%$, наслідки для суб'єктів малого та середнього бізнесу $€$ більш руйнівними. Схематично вплив карантинних заходів на роботу МСП зображено на рис. 1.

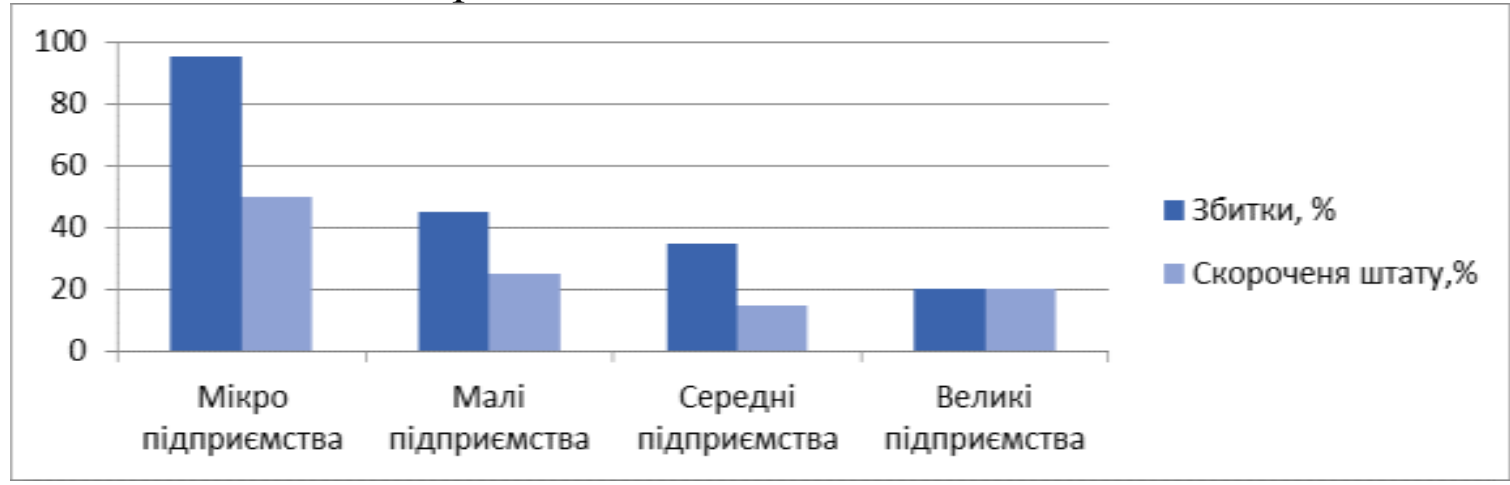

Рис. 1. Вплив заходів карантину на стан МСБ та великих підприємств Джерело: складено автором за даними [7]

Таким чином, ми бачимо, що найбільших грошових збитків зазнав мікро та МСБ, порівнюючи з великим, проте, скорочення штатів працівників на великих підприємства відбулося на рівні з меншими підприємствами.

Для розробки ефективних заходів, які сприятимуть подоланню негативних наслідків пандемії, необхідно проаналізувати досвід провідних зарубіжних країн, а також дослідити способи урядової підтримки МСБ Свропейських країн і США. Заходи, які застосовують країни $\mathrm{CC}$, Англія та США для допомоги малому та середньому бізнесу в період короновірусної економічної кризи, можна згрупувати за трьома категоріями (рис.

\section{1. Негайний фіскальний імпульс}

додаткові витрати державою та упущені надходження (Німеччина, США, Польща, Франція)

\section{2. Відстрочення}

відстрочити певні платежі, включаючи податки та внески на соціальне страхування

(США, Фінляндія, Велика Британія)

3. Інші
положення та
гарантії
ліквідності

включають експортні гарантії, допомогу ліквідності, кредитні лінії через національні банки розвитку (США, Велика Британія, Франція)

Рис. 2. Дискреційні фіскальні заходи впливу на економічну кризу COVID-19 Джерело: згруповано автором за даними [8] 
На додаток до нових заходів щодо витрат, деякі уряди відкладають або скасовують деякі раніше заплановані витрати, наприклад деякі інвестиції. Частково це пов'язано 3 необхідністю надати більше фіскальних ресурсів для боротьби з пандемією та іiі економічними наслідками, а частково - через перебої в постачанні. Таке скорочення витрат $\epsilon$ негативним фіскальним імпульсом. Через брак даних ми не можемо кількісно оцінити ці зменшені витрати.

Заходи, які запроваджує уряд України для подолання негативних наслідків кризи, спричиненою пандемією, спрямовані на підтримку бізнесу, а особливу малого та середнього. У 2020 році влада запровадила низку заходів реагування на кризу, сума яких становила близько $3 \%$ від ВВП країни. Першими в Україні були запроваджені такі заходи: податкові пільги; розширені програми субсидованих кредитів; ефективні та доступні схеми кредитних гарантій; програми соціальної підтримки.

Додаткова урядова підтримка буда надана домогосподарствам та деяким підприємствам, наприклад, у вигляді відстрочки або дозволу невиплачувати штрафні санкції за затримку погашення кредитних зобов'язань. У грудні 2020 року будо ухвалено парламентом низку заходів для підтримки бізнесу, в основному мікро (ФОП), малого та середнього, під час другої хвилі карантинних обмежень. Вони включали одноразову грошову допомогу в розмірі 8000 грн (280 доларів США) найманим працівникам та індивідуальним підприємцям, які в результаті карантину втратили свої доходи, а також деяких ФОП було звільнено від сплати податку на прибуток та соціальне страхування 3 грудня 2020 року по травень 2021 року та списано 3 них податкові борги на суму не вище 3060 грн. До 2021 року діяла програма субсидованих кредитів. Крім того, уряд затвердив державні гарантії на суму 180 мільйонів доларів для кредитування банківського бізнесу.

Уряд України затвердив програму економічного стимулювання для ефективного подолання наслідків епідемії COVID-19, яка включає пропозиції щодо підтримки конкретно малого та середнього бізнесу. У березні 2020 року НБУ запропонував банкам запровадити особливий період відстрочки кредитування на період карантину для ФОП та МСБ - «кредитну відпустку». НБУ також створив сприятливе середовище для підтримки монетарних (зниження ключової ставки, рефінансування) та регуляторних операцій (відкладення нових вимог до капіталу, стрес-тести та контролю, вимоги до банківської звітності та інші пом'якшення).

Україною було застосовано такі загальносвітові підходи для стабілізації економіки та підтримки МСП у часи карантинних обмежень (рис.3). Слід також зазначити, що для стабілізації $\mathrm{i}$ майбутнього розвитку економіки України, особливо в карантинних умовах, слід розвивати краудфандинг, що активно практикують закордоном. Залучення коштів за рахунок внесків від великої кількості сторонніх осіб можливе за рахунок розміщення своїх бізнес-ідей або інших бізнеспропозицій в мережі Інтернет через сучасні спеціалізовані платформи. Це дасть змогу залучати кошти не лише від внутрішніх інвесторів, а й від інвесторів із за кордону $[9,10,11]$. 


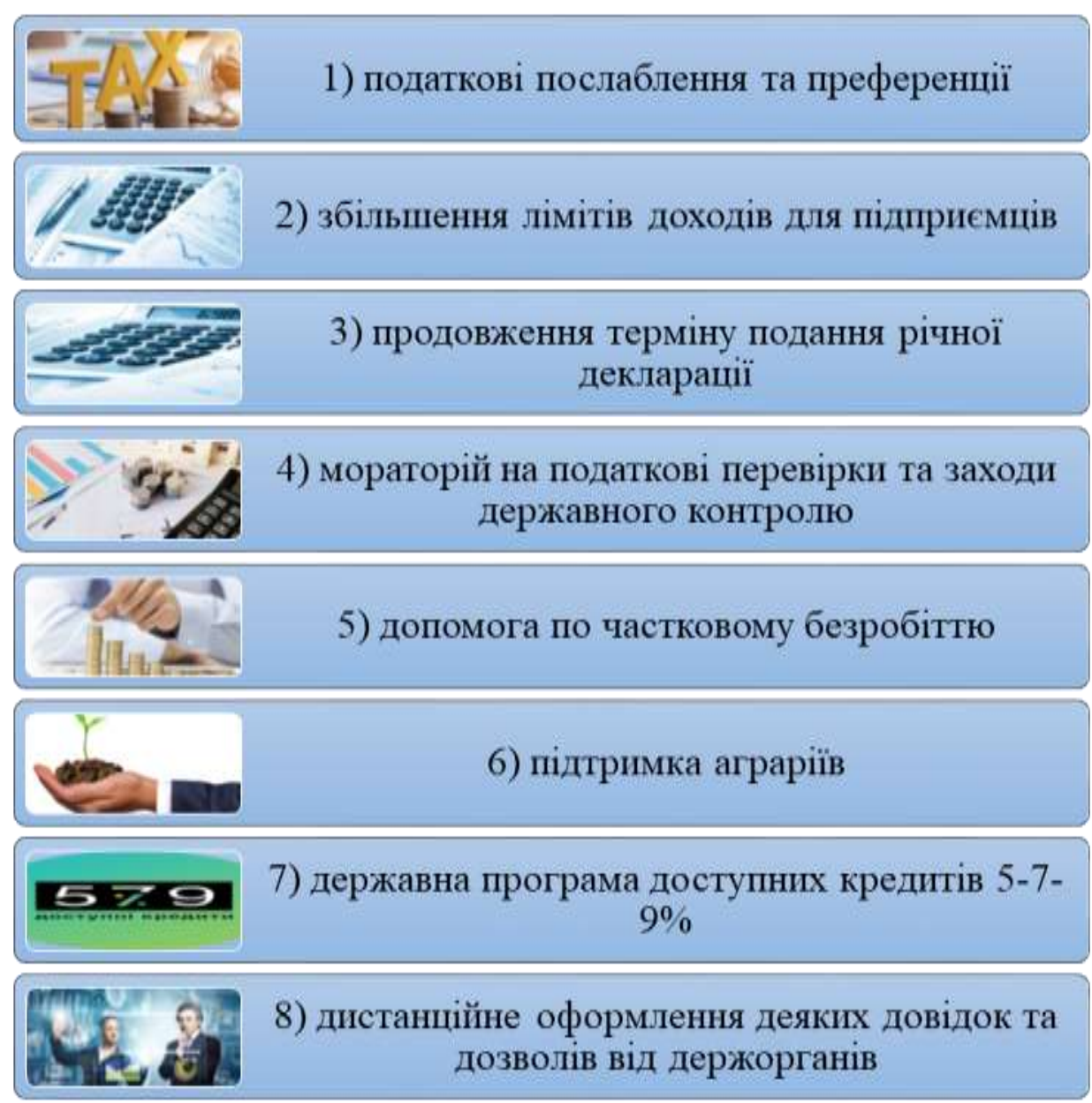

Рис. 3. Державні заходи підтримки МСБ та ФОП під час пандемії COVID-19 Джерело: згруповано автором за даними [12]

Таким чином, в умовах кризи важливо створити гнучку систему оподаткування та адміністрування податкових платежів не лише для подолання нинішньої економічної кризи бізнесу та економіки, а й вжити заходів щодо пом'якшення iï негативних соціальноекономічних наслідків, що дасть змогу швидко та ефективно реагувати подібні ситуації в майбутньому. Це можуть бути переваги для окремих регіонів, секторів та видів діяльності, які мають стратегічне та різне значення для регіону чи держави в цілому. Важливо пам'ятати про справедливість оподаткування. «Справедливість оподаткування має грунтуватися на гармонійному поєднанні фінансових інтересів держави, суспільства та плат- ників податків» $[13,14,15]$. Ми вважаємо, що найбільш ефективними для України $є$ запровадження таких заходів:

- подовження періоду скасування жорстких умов сплати податків на певний період;

- перенесення термінів сплати податків та решти податкових платежів у разі неспроможності вчасної сплати, особливо в період дії карантинних обмежень;

- зменшення на 50\% або скасування не менше ніж на 6 місяців ССВ із збереженням усіх робочих місць за роботодавцем;

- зменшення або скасування податку на прибуток підприємств не менше 
ніж на 6 місяців 3 повним відновленням діяльності;

- додаткові податкові пільги, які швидко відновлять та прискорять темпи економічного розвитку.

Висновки. Отже, підтримка малого та середнього бізнесу і економіки вцілому, має відігравати важливу роль серед основних заходів допомоги під час економічної кризи, яка спричинена пандемією COVID-19. Безпосереднім у цьому відношенні $є$ негайне створення «Програми допомоги для підтримки бізнесу». Для великих і середніх підприємств доцільним є надання необмеженої кількість кредитних коштів, доступних за різними кредитними схемами та зменшеними ставками; заморожування виплат платежів за раніше отриманими кредитами та позиками; відстрочення платежів платникам податків з прибутку підприємств.
Для малих підприємців необхідно рекомендувати: перенесення дати сплати податків та інших податкових зборів у разі неможливості такої сплати, особливо на період карантину; зменшення або скасування не менше 6 місяців податку на доходи фізичних осіб та ССВ iз збереженням усіх робочих місць за роботодавцем; зменшення або скасування податку на прибуток підприємств не менше ніж на 6 місяців 3 повним відновленням діяльності; надання пільгових кредитів за «Програмою підтримки малого бізнесу та самозайнятості»; спрямування відповідних коштів на надання одноразових дотацій, повернення яких не передбачено; утримання оборотних коштів для покриття трьох карантинних витрат; додаткові податкові пільги, що дозволяють швидко відновитися та збільшити темпи розвитку малого бізнесу.

\section{Список використаної літератури}

1. Richard Baldwin, Beatrice Weder di Mauro (2020). Mitigating the COVID Economic Crisis: Act Fast and Do Whatever It Takes. CERP Press. URL: https://www.researchgate.net/publication/342961959_Mitigating_the_COVID_Econo mic_Crisis_Act_Fast_and_Do_Whatever_It_Takes_A_VoxEUorg_Book (дата звернення: 29.11.2021).

2. Joseph Amankwah-Amoaha, Zaheer Khanb, Geoffrey Woodc (2020). COVID19 and business failures: The paradoxes of experience, scale, and scope for theory and practice. European Management Journal, DOI: https://doi.org/10.1016/j.emj.2020.09.002 (дата звернення: 29.11.2021).

3. Ворфоломеєв A.В. Вплив COVID-19 на українські виробничі підприємства та допомога у відновленні нормальної роботи: звіт за результатами опитування Центру ресурсоефективного та чистого виробництва. Київ: Центр ресурсоефективного та чистого виробництва, 2020. 24 с.

4. Вплив COVID-19 та карантинних умов на економіку України / уклад. Д. Дєнков, А. Каракуц, Ю. Щедрін. Київ : Центр прикладних досліджень, 2020. 56 c.

5. Свєшніков С. В., Бочарніков В. П., Полякова О. В. Коронавірус і безпекове середовище: спроба неупередженого аналізу. Збірник наукових праиь Центру воєнно-стратегічних досліджень НУОУ імені Івана Черняховського. 2020. № 2-69. C. 22-29. 
6. Офіційний сайт Державної служби статистики України. URL: http://ukrstat.gov.ua/operativ/menu/menu_u/sze.htm(дата звернення: 30.11.2021).

7. Офіційний сайт Спілки Українських Підприємців. URL: http://sup.org.ua/uk (дата звернення: 30.11.2021).

8. Julia Anderson, Enrico Bergamini, Sybrand Brekelmans, Aliénor Cameron, Zsolt Darvas, Marta Domínguez Jíménez, Klaas Lenaerts, Catarina Midões (2020). The fiscal response to the economic fallout from the coronavirus. BRUEGEL DATASETS. URL: https://www.bruegel.org/publications/datasets/covid-nationaldataset/?utm_content=buffer99084\&utm_medium=social\&utm_source=twitter.com\&utm _campaign=buffer+(bruegel) (дата звернення: 30.11.2021 ).

9. Tanklevska, N., Povod, T., Ostapenko, A., Borovik, L. (2021) Crowdfunding Development Trends: Foreign Experience and Ukrainian Realities in the Digital Economy. Conference Paper. Lecture Notes in Networks and Systems. 194 LNNS, p. 897-908.

10. Петренко В.С., Карнаушенко А.С. Поняття краудфандингу та його роль в національній економіці. Таврійський науковий вісник. Серія: Економіка. Випуск 2, 2020. С. 140-150.

11. Повод Т.М., Остапенко А.С. Краудфандинг як перспективне джерело фінансування бізнесу. Східна Свропа: економіка, бізнес та управління. Випуск 5 (16). 2019. С. 235-240.

12. Дякуновський О. Щодо державної підтримки суб’єктів малого та середнього підприємництва в умовах пандемії коронавірусної хвороби (COVID-19) у республіці Польща та Україні. Knowledge, Education, Law, Management. 2020. № 3 (31), vol. 1. C. 181-189.

13. Зельдіна О., Гришко В. Податкові стимули як складник справедливого оподаткування. Господарське право і процес. 2017. №10. С.67-71.

14. Танклевська Н. С., Кирилов Ю.Є., Зайцева О.І. Управління усвідомленими адаптивними організаціями в умовах соціально-економічних трансформацій та фінансової турбулентності. Науковий вісник Полісся. 2017. № 4 (12). С. 36-39.

15. Танклевська Н.С. Сучасні тренди розвитку жіночого підприємництва в Україні. Фінансовий простір. 2020. № 3(39). С. 80-90. 